\title{
IN DEFENSE OF THE USE OF ITALIC FOR LATIN BINOMIAL PLANT NAMES ${ }^{1}$
}

\author{
Jaime A. TeIXeIra DA Silva
}

\begin{abstract}
The author surveyed the instructions for authors in 110 botanical journals to assess how widely italic is used to represent the Latin binomial names of plants. Except for one journal that eliminated italic from the reference list, all of these journals published articles that used italic in the text and reference list for Latin binomial names of plants. However, in their instructions for authors only $48 \%$ of these journals explicitly requested the use of italic to denote the Latin binomial names of plants.
\end{abstract}

Key words: botanical nomenclature, IAPT, ICNCP, journal style standards, instructions for authors, latinization

Jaime A. Teixeira da Silva, P. O. Box 7, Miki-cho post office, Ikenobe 3011-2, Kagawa-ken, 761-0799, Japan; e-mail:jaimetex@yahoo.com

In botany, italic is generally used for the Latin binomial names of plants. To assess how widely and how systematically italic is used to represent the Latin binomial names of plants among botanical journals, first I contacted several experts on taxonomy to survey their opinions (see Acknowledgements). These experts included John McNeill and Nicholas J. Turland, the authors of the preface to the latest code for plant nomenclature established by the International Association for Plant Taxonomy (IAPT), the International Code of Nomenclature for algae, fungi, and plants (Melbourne Code) (McNeill et al. 2012). Then I surveyed 110 journals linked to botany to determine whether they employ italic in text, and whether their instructions for authors specifically require the use of italic for botanical names.

As pertains to the use of italic for Latin botanical names, the Code states: 'As in all recent editions, scientific names under the jurisdiction of the Code, irrespective of rank, are consistently printed in italic type. The Code sets no binding standard in this respect, as typography is a matter of editorial style and tradition, not of nomenclature. Nevertheless, editors and authors, in the interest of international uniformity, may wish to consider adhering

\footnotetext{
1 Invited paper
}

to the practice exemplified by the Code, which has been well received in general and is followed in a number of botanical and mycological journals. To set off scientific names even better, the abandonment in the Code of italic for technical terms and other words in Latin, traditional but inconsistent in early editions, has been maintained.'

In October 2014 I obtained the following opinions through personal communication, quoted verbatim here:

Prof. Turland stated that the use of italic is voluntary: 'I can confirm that the International Code of Nomenclature for algae, fungi, and plants does not rule on or even formally recommend the use of italic for scientific names of organisms. It does, however, consistently use italic for all scientific names at all ranks. See the comments in the Preface to the Melbourne Code (McNeill \& Turland 2012). Here it is stated that the use of italic is a matter of editorial style and tradition, not of nomenclature. I would think it quite unorthodox if a journal never used italic for scientific names in any context. However, not using italic in the literature cited is perhaps another matter, as styles of citing references vary so much, e.g. with use or non-use of commas, full stops, spaces, capital letters, etc.'

Prof. Feliner reinforced this optional position regarding the use of italic: 'I don't think the 
procedure followed by the journal is wrong. Neither the International Code of Nomenclature for algae, fungi, and plants (McNeill et al. 2012) nor the previous editions impose a compulsory norm concerning typography of scientific names. But, what is more important, the scientific names within the main text are in italic (aren't they?) so that they can easily be identified as such. This is the main utility of using italic for scientific names. In a reference list, if all the items are scientific names, there is no need to use the italic throughout the list unless you want to distinguish, e.g., accepted names from synonyms and/or common names. Then there is a (perhaps unwritten) rule for typographers, that is, to keep italic to a minimum, and probably this is the reason why they remove them from the reference list.'

Prof. Simpson's opinion was aligned with those of the experts quoted above: 'Although it is common usage to put all taxa of species and below in italic, it is not required by the International Code of Nomenclature (ICN). (In fact, the $I C N$ italicizes names of all ranks, which is not generally done in journals.) As in all recent editions, scientific names under the jurisdiction of the Code, irrespective of rank, are consistently printed in italic type. The Code sets no binding standard in this respect, as typography is a matter of editorial style and tradition, not of nomenclature. [This] varies with the journal and is not required by the $I C N$.' Dr. McNeill, Dr. Funk and Dr. Katinas recommended that the Code should be followed.
Three professors defended the use of italic. Prof. Gradstein stated that 'putting scientific names of genera and all taxa below the genus level, including species, in italic is a standard editorial policy that is applied by all scientific impact journals (with IF) that I am familiar with.' Prof. Marhold argued that 'The typesetting of names of plant genera and species in italic is editorial convention. It is not introduced as a rule in the codes of nomenclature. Saying that, I have to say also that all botanical journals, as far as I am aware, are accepting this convention, both in the main text and in references. The same practice is kept in the codes of nomenclature.' Prof. Schmid fortifies this position: 'The use of italic for the so-called scientific names of organisms (genus, species, infraspecific taxa) is a practice of very long standing. I am not aware of any important contemporary biological journal that does not use italic for such cases. From my viewpoint and that of Taxon: International Journal of Plant Taxonomy, Phylogeny and Evolution, the use of italic for Latin names of organisms is essential for accuracy and clarity. Style manuals such as the Chicago Manual of Style (Editions 15, 16), which is the one many journals. including Taxon, use, also advocate the use of italic in such cases.' In the latter comment Prof. Schmid is referring to http://www.chicagomanualofstyle. org/home.html.

Analysis of the most prominent and accessible botanical journals from around the globe revealed the following (Table 1):

Table 1. Selected botanical journals ${ }^{1}$, their use of italic, and any policies or guidelines regarding the use of italic for binomial nomenclature (see URLs in Supplementary file).

\begin{tabular}{|c|c|c|}
\hline Journal & $\begin{array}{l}\text { Use of } \\
\text { italic in } \\
\text { articles }^{2}\end{array}$ & Explicit statements on italic, if any, in instructions for authors ${ }^{3}$ \\
\hline Acta Botanica Brasilica & Yes & None \\
\hline Acta Botanica Croatica & Yes & None \\
\hline Acta Botanica Fennica & Yes & $\begin{array}{l}\text { 'The following should always be italicised: } 1 \text {. Scientific names } \\
\text { at genus level and below. } 2 . \text { In author citations, ex and in. } 3 \text {. } \\
\text { Latin words, such as sensu, pro parte, non, etc. } 4 \text {. Entire Latin } \\
\text { description. } 5 \text {. In specimen citations, collector's name and } \\
\text { collecting number (see examples below).' }\end{array}$ \\
\hline Acta Botanica Hungarica & Yes & $\begin{array}{l}\text { 'Latin names of genera, species, infraspecific taxa and plant } \\
\text { associations should be in italic (except in the list of references).' }\end{array}$ \\
\hline Acta Botanica Gallica: Botany Letters & Yes & None \\
\hline
\end{tabular}


Table 1. Continued.

\begin{tabular}{|c|c|c|}
\hline Journal & $\begin{array}{l}\text { Use of } \\
\text { italic in } \\
\text { articles }^{2}\end{array}$ & Explicit statements on italic, if any, in instructions for authors ${ }^{3}$ \\
\hline Acta Botanica Mexicana & Yes & None \\
\hline Acta Horticulturae & Yes & $\begin{array}{l}\text { 'Scientific names are to be included for all plant species and are to } \\
\text { be in italic font except for the abbreviations 'var.', 'subsp.', 'f.', } \\
\text { etc. which indicate rank at infraspecific level' }\end{array}$ \\
\hline Alpine Botany & Yes & None \\
\hline American Journal of Botany & Yes & None \\
\hline Anales del Jardín Botánico de Madrid & Yes & $\begin{array}{l}\text { 'En lo que respecta a los nombres científicos, sólo los de nivel } \\
\text { genérico o inferior están en cursiva.' }\end{array}$ \\
\hline Annals of Botany & Yes & None \\
\hline Annals of the Missouri Botanical Garden & Yes & 'Only taxon names at the rank of genus and below are italicized.' \\
\hline Aquatic Botany & Yes & None \\
\hline Australian Journal of Botany & Yes & None \\
\hline Australian Systematic Botany & Yes & None \\
\hline Bangladesh Journal of Botany & Yes & None \\
\hline Biologia (sect. Botany) & Yes & None \\
\hline Biologia Plantarum & Yes & None \\
\hline Biological Journal of the Linnean Society & Yes & $\begin{array}{l}\text { 'Names of genera and species should be printed in italic or } \\
\text { underlined to indicate italic' }\end{array}$ \\
\hline Biotecnología Vegetal & Yes & None \\
\hline Biotropica & Yes & None \\
\hline BMC Plant Biology & Yes & None \\
\hline Boletín de la Sociedad Argentina de Botánica & Yes & $\begin{array}{l}\text { 'The Latin names designating genera, species, subspecies and } \\
\text { varieties should be written in italics' }\end{array}$ \\
\hline Botanica Lithuanica & Yes & 'All names of taxa and syntaxa should be printed in italic type.' \\
\hline Botanica Marina & Yes & None \\
\hline Botanica Serbica & Yes & None \\
\hline Botanical Journal of the Linnean Society & Yes & 'Names of genera and species should be printed in italic.' \\
\hline Botanical Review (The) & Yes & None \\
\hline Botanical Studies & Yes & None \\
\hline Botany & Yes & None \\
\hline Brazilian Journal of Botany & Yes & None \\
\hline Bryonora & Yes & Unclear (in Czech) \\
\hline Candollea & Yes & Unclear \\
\hline Caryologia & Yes & None \\
\hline Central European Journal of Biology ${ }^{4}$ & Yes $^{5}$ & $\begin{array}{l}\text { 'All Latin names should be italicized, including species names and } \\
\text { common structures.' }\end{array}$ \\
\hline Chloris Chilensis & Yes & None. No Instructions for authors. \\
\hline Collectanea Botanica & Yes & None \\
\hline Cryptogamie & Yes & None \\
\hline Economic Botany & Yes & None \\
\hline Edinburgh Journal of Botany & Yes & 'Genus and species names should be italicised' \\
\hline Ethnobotany Research and Applications & Yes & 'any genus/species names italicized' \\
\hline European Journal of Horticultural Science & Yes & 'Species should be written in italics, e.g. Malus domestica Borkh.' \\
\hline Folia Geobotanica & Yes & 'Genus and species names should be in italics.' \\
\hline Folia Horticulturae & Yes & 'Latin names should be in italic.' \\
\hline Frontiers in Plant Science & Yes & None \\
\hline Gayana Botanica & Yes & 'Use italics for scientific names' \\
\hline Grana & Yes & $\begin{array}{l}\text { 'Scientific names of genera and taxa of lower rank must be in } \\
\text { italics.' }\end{array}$ \\
\hline
\end{tabular}


Table 1. Continued.

\begin{tabular}{|c|c|c|}
\hline Journal & $\begin{array}{l}\text { Use of } \\
\text { italic in } \\
\text { articles }^{2}\end{array}$ & Explicit statements on italic, if any, in instructions for authors ${ }^{3}$ \\
\hline Guineana & Yes & None \\
\hline Harvard Papers in Botany & Yes & None \\
\hline Horticulture Journal (The) & Yes & $\begin{array}{l}\text { 'The scientific name of the genus, species, and subspecies should } \\
\text { be given in italics' }\end{array}$ \\
\hline International Journal of Plant Sciences & Yes & None \\
\hline $\begin{array}{l}\text { In Vitro Cellular and Developmental Biology } \\
\text { - Plant }\end{array}$ & Yes & None \\
\hline Journal of Applied Botany and Food Quality & Yes & $\begin{array}{l}\text { 'Generally, scientific names of plants and animals should be } \\
\text { printed in italics.' }\end{array}$ \\
\hline Journal of Experimental Botany (The) & Yes & None \\
\hline Journal of Integrative Plant Biology & Yes & None \\
\hline Journal of Japanese Botany (The) & Yes & 'Scientific names are indicated with italic font.' \\
\hline Journal of the Adelaide Botanic Gardens & Yes & 'Italicise in the text the following: scientific names' \\
\hline $\begin{array}{l}\text { Journal of the American Society for } \\
\text { Horticultural Science }\end{array}$ & Yes & $\begin{array}{l}\text { 'Use italics for the following: The scientific name of a genus, } \\
\text { species, or subspecies' }\end{array}$ \\
\hline $\begin{array}{l}\text { Journal of the Botanical Research Institute } \\
\text { of Texas }\end{array}$ & Yes & None \\
\hline Journal of the Torrey Botanical Society (The) & Yes & 'Binomials should be formatted in italics.' \\
\hline Kew Bulletin & Yes & $\begin{array}{l}\text { 'Italics are used for the following: plant names at genus level and } \\
\text { below' }\end{array}$ \\
\hline Lagascalia & Yes & None \\
\hline Lankesteriana & Yes & 'Italicize all scientific names at the generic level or below.' \\
\hline Lazaroa & Yes & $\begin{array}{l}\text { 'Texts should be written in normal type letters using cursive only } \\
\text { for scientific nomenclature.' }\end{array}$ \\
\hline Lichenologist (The) & Yes & None \\
\hline Lindbergia & Yes & None \\
\hline Madroño & Yes & None \\
\hline Maydica & Yes & $\begin{array}{l}\text { 'Italicize names of organisms only when the species is indicated: } \\
\text { Neurospora, but Neurospora crassa or } N \text {. crassa.' }\end{array}$ \\
\hline Mycologia & Yes & $\begin{array}{l}\text { 'Italicize only generic, infrageneric (subgenus, section), specific } \\
\text { and infraspecific taxa.' }\end{array}$ \\
\hline Mycorrhiza & Yes & 'Genus and species names should be in italics.' \\
\hline Nature Plants & Yes & None \\
\hline New Journal of Botany & Yes & $\begin{array}{l}\text { 'Italics: use for formally recognised plant associations; in plant } \\
\text { names where appropriate, e.g. Carex recta Boott (Cyperaceae); } \\
\text { and for Latin phrases and abbreviations ( } \text { such as } c \text {. [ circa }] \text {, et al., } \\
\text { et seq.), should be in italics.' }\end{array}$ \\
\hline New Phytologist & Yes & None \\
\hline New Zealand Journal of Botany & Yes & 'Generic and specific names should be in italics.' \\
\hline $\begin{array}{l}\text { New Zealand Journal of Crop and } \\
\text { Horticultural Science }\end{array}$ & Yes & '...generic and species names should be in italics.' \\
\hline Nordic Journal of Botany & Yes & 'Only scientific plant names ... in Latin should be italizied [sic]' \\
\hline Novon & Yes & 'Only taxon names at the rank of genus and below are italicized.' \\
\hline Nuytsia & Yes & $\begin{array}{l}\text { 'Italics are used for all ... standard Latin abbreviations when } \\
\text { attached to a formal scientific name' }\end{array}$ \\
\hline Pakistan Journal of Botany & Yes & None \\
\hline Phytokeys & Yes & $\begin{array}{l}\text { 'Scientific names of taxa of species and genera... should be } \\
\text { italicized.' }\end{array}$ \\
\hline Phytologia & Yes & None \\
\hline
\end{tabular}


Table 1. Continued.

\begin{tabular}{|c|c|c|}
\hline Journal & $\begin{array}{l}\text { Use of } \\
\text { italic in } \\
\text { articles }^{2}\end{array}$ & Explicit statements on italic, if any, in instructions for authors ${ }^{3}$ \\
\hline Phytologia Balcanica & Yes & $\begin{array}{l}\text { 'Scientific plant names, irrespective of rank, should be given in } \\
\text { italics.' }\end{array}$ \\
\hline Phyton & Yes & None \\
\hline Phytopathology & Yes & None \\
\hline Phytotaxa & Yes & 'Generic names and all ranks below are italicised.' \\
\hline Plant Biology & Yes & 'Latin names should be underlined or typed in italics.' \\
\hline Plant Biosystems & Yes & None \\
\hline Plant Ecology and Evolution & Yes & 'Only names at genus level and below are put in italics.' \\
\hline Plant Science & Yes & None \\
\hline Plant Systematics and Evolution & Yes & 'Generic and infrageneric names should be in italics' \\
\hline Planta & Yes & 'Genus and species names should be in italics.' \\
\hline Polibotánica & Yes & None \\
\hline Polish Botanical Journal & Yes & 'For Latin names of genera and taxa of lower rank use italics.' \\
\hline Preslia & Yes & None \\
\hline Review of Palaeobotany and Palynology & Yes & $\begin{array}{l}\text { 'Genera and species names are to be written in italics, whereas } \\
\text { higher taxonomical units are written in normal font.' }\end{array}$ \\
\hline Rhodora & Yes & 'Names at the rank of genus and below should be italicized.' \\
\hline Rodriguésia & Yes & $\begin{array}{l}\text { 'Latin must appear in italic type-face (incl. genus and species } \\
\text { names).' }\end{array}$ \\
\hline South African Journal of Botany & Yes & None \\
\hline Steciana & Yes & Unclear (in Polish). \\
\hline Studia Botanica Hungarica & Yes & $\begin{array}{l}\text { 'Names of genera, species, subspecies, varieties and forms should } \\
\text { be italicised' }\end{array}$ \\
\hline Svensk Botanisk Tidskrift & Yes & Unclear (in Swedish) \\
\hline Systematic Botany & Yes & None \\
\hline Systematics and Biodiversity & Yes & None \\
\hline Taxon & Yes & None \\
\hline Telopea & Yes & None \\
\hline Thaiszia Journal of Botany & Yes & Unclear \\
\hline Tuexenia & Yes & $\begin{array}{l}\text { 'All Scientific names of plants and plant communities are to be } \\
\text { written in italics, e. g. Viola tricolor subsp. alpestris' }\end{array}$ \\
\hline Turkish Journal of Botany & Yes & $\begin{array}{l}\text { 'All scientific names cited in the running text, irrespective of rank, } \\
\text { must be italicised.' }\end{array}$ \\
\hline Webbia & Yes & None \\
\hline Willdenowia & Yes & None \\
\hline
\end{tabular}

1 Journals were screened from 1255 journals listed at http://web.archive.org/web/20150214092343/http://www.e-journals.org/ botany/ The comparative table includes only journals that were still actively publishing at the time of writing and are directly related to botany, or more general plant science journals requiring botanical nomenclature and for which a web-site existed with a visible/accessible archive and clear instructions for authors. Journals related to agronomy, agriculture, biotechnology, breeding, ecology, forestry, physiology or soil science were excluded, but selected horticultural journals are included. Also, journals or publishers listed at www.scholarlyoa.com were excluded.

${ }^{2}$ To determine this criterion at least three full text articles from 2014/2015 were accessed.

${ }^{3}$ Even if an example using italic was given in the instructions for authors, the IFA must specifically use the word 'italic(s)'.

${ }^{4}$ The publisher and journal name (Open Life Sciences) changed in January, 2015: http://www.degruyter.com/view/j/biol.

${ }^{5}$ Italic is used in the text but is removed from the reference list by the publisher. 
- except for one journal (Central European Journal of Biology) which eliminated italic from the reference list, all of the 110 examined journals published articles employing italic for Latin binomial names of plants in the text and reference list;

- the instructions for authors of 53 of the journals $(48 \%)$ clearly request the use of italic to denote the Latin binomial names of plants.

The ICN (McNeill et al. 2012) does not explicitly forbid the lack of italic for the Latin botanical names of plants, but it encourages the use of italic. This also appears to be the position held by the majority of expert botanists and plant taxonomists whose opinions I sought. Though fewer than half of the botanical journals examined had an explicit requirement for the use of italic for botanical names in their instructions for authors, the general sense is that italic should be used for such instances uniformly in the text and reference list. The next version of the IAPT should revise the $I C N$ to make the use of italic compulsory, simply because, as for other clauses of the Code, it is based on a rich tradition and historical use.

ACKNOwLEDGEMENTS. For fruitful discussions which helped to clarify a number of issues I thank the following experts: Prof. Nicholas J. Turland (Botanischer Garten und Botanisches Museum Berlin-Dahlem Freie
Universität Berlin, Berlin, Germany), Prof. S. Robbert Gradstein (Muséum National d'Histoire Naturelle, Paris, France), Prof. Gonzalo Nieto Feliner (Real Jardín Botánico, CSIC, Madrid, Spain), Prof. Rudolf Schmid (University of California, CA, USA), Prof. Karol Marhold (Institute of Botany, Bratislava, Slovak Republic), Dr. Michael G. Simpson (San Diego State University, CA, USA), Dr. John McNeill (Royal Botanic Garden, Edinburgh, UK), Dr. Vicky Funk (Smithsonian Institution and National Museum of Natural History, Washington DC, USA), Dr. Lilina Katinas and Dr. Jorge V. Crisci (Museo de La Plata, La Plata, Argentina), and Dr. Xian-Chun Zhang (Institute of Botany of the Chinese Academy of Sciences, Beijing, China).

\section{REFERENCES}

McNeill J. \& Turland N. J. 2012. Preface. In: J. McNeill, F. R. Barrie, W. R. Buck, V. Demoulin, W. Greuter, D. L. Hawksworth, P. S. Herendeen, S. Knapp, K. Marhold, J. Prado, W. F. Prud'homme van Reine, G. F. Smith, J. H. Wiersema \& N. J. Turland, International Code of Nomenclature for algae, fungi and plants (Melbourne Code). Regnum Veg. 154: ix-xxii.

McNeill J., Barrie F. R., Buck W. R., Demoulin V., Greuter W., Hawksworth D. L., Herendeen P. S., Knapp S., Marhold K. , Prado J., Prud'homme van Reine W. F., Smith G. F., Wiersema J. H. \& Turland N. J., International Code of Nomenclature for algae, fungi and plants (Melbourne Code). Regnum Veg. 154: ix-xxii + 1-240. 